\title{
Time, Digression and the Other (Side) in Juan José Saer's La grande
}

Juan José Saer (1937-2005) is seen by many as Argentina’s greatest contemporary writer: his fellow Argentine, Ricardo Piglia (1941-2017), a writer of international reputation himself and probably better known than Saer, has described him as 'uno de los mejores escritores actuales en cualquier lengua $[\ldots]^{\prime} .{ }^{1}$

He remains, however, something of a dark horse, having spent a lifetime (mainly in Paris rather than in Argentina) avoiding publicity: Premat notes that he rejected 'los poses, los mitos, los rituales’ and refers to ‘el silencio mediático que caracterizó buena parte de su carrera'. ${ }^{2}$ It is probably still true to say, alongside Corbatta, that Saer is relatively unknown. ${ }^{3}$ The settings of his work suggest a regionalist writer: the Santa Fe area and the banks of the Paraná river are constant features. Their prominence, enhanced in Saer’s final work, $L a$ grande, contributes, through their 'development', to one of the work's major themes: the

\footnotetext{
${ }^{1}$ Juan José Saer and Ricardo Piglia, Diálogo, Biográficos Mangos de Hacha, Delegación Álvaro Obregón (México: Mangos de Hacha, 2010), p. 39.

${ }^{2}$ Julio Premat, ‘¿Cómo ser escritor? El caso Saer’, in Juan José Saer and Ricardo Piglia, Entre ficción y reflexion, ed. by Rose Corral (México, D.F.: El Colegio de México. Centro de Estudios Lingüísticos y Literarios, 2007), pp. 218-19.

${ }^{3}$ Jorgelina Corbatta, 'En la zona: germen de la praxis poética de Juan José Saer’, Revista Iberoamericana, 57 155-56 (1991), 557-67 (p. 558).
} 
passage of time. ${ }^{4}$ Despite his local settings, however, Saer is not a regionalist writer, his work displaying, in this respect, a similar quality to the poetry of his fellow Argentine, Juan L. Ortiz (1896-1978): in Sarlo’s formulation, ‘un regionalismo no regionalista’. ${ }^{5}$ Piglia concurs: 'su obra [...] está situada al otro lado de las fronteras, en esa tierra, sin propiedad y sin patria, que es el lugar mismo de la literatura'. ${ }^{6}$

La grande, Saer's final novel, was published posthumously, and of such works to elude critical understanding and mastery. ${ }^{7}$ It is an incomplete text: Saer died while working on the final chapter according to an editorial note ('Algunas precisiones sobre esta edición’ by

\footnotetext{
${ }^{4}$ The changes affecting the Santa Fe region are documented by Raquel Linenberg-Fressard in 'La ciudad en el tiempo: La grande (2005) de Juan José Saer', in Les Villes et la fin du XXe siècle en Amérique latine: Littératures, cultures, représentations/Las ciudades y el fin del siglo XX en América Latina: Literaturas, culturas, representaciones, ed. by Teresa Orecchia-
} Havas (Berlin: Peter Lang, 2007), pp. 357-67.

${ }^{5}$ Beatriz Sarlo, 'Juan L. Ortiz’, in Escritos sobre literatura argentina, ed. by Sylvia Saítta (Buenos Aires: Siglo XXI Editores, 2007), pp. 269-77 (pp. 269-70).

${ }^{6}$ Saer and Piglia, Diálogo, p. 39.

${ }^{7}$ Juan José Saer, La grande (Buenos Aires: Seix Barral, 2005). Referring to Robert Musil’s The Man Without Qualities, the narrator of Nuria Amat's Todos somos Kafka reserves specific praise for the posthumous volume: ‘de obras póstumas e incomprendidas han salido grandes obras'. The unpublished work becomes a secret treasure at a time when the reading public is sated with 'tantas obras comprendidas y publicadas'. Nuria Amat, Todos somos Kafka, prólogo de Carlos Fuentes (Barcelona: Reverso 2004 [1995]), p. 71. 
‘A.D', pp. 437-38). We also learn from 'A.D' that there is no indication of how the text might have ended, apart from Saer's intention to close with the words, 'Moro vende', suggesting the sale of the house owned by Gutiérrez, one of the main characters. The purpose of this article is to demonstrate that La grande both contributes to the thematic continuity based on the dissipation of reason that unifies Saer's oeuvre and also marks a new and more positive direction, a joyousness deriving from fresh perspectives on the commonplace episodes of daily existence. The text may focus on lack, distance, dysfunction and loss but their usual associations are - at least to some extent - reconfigured positively, by contrast with such universally privileged values as coherence, reason and logic that are undermined. This is a blatantly digressive text that flaunts its lack of structural coherence, rigour and unity, and indulges, like Nula its protagonist, its freedom to roam. Disability, usually equated with disadvantage and handicap, is often portrayed affirmatively in La grande, as liberating human potential and heightening the powers of sensation and sensitivity. Its prominence as a figure of the unstable and transgressive contributes to the reader's sense of textual orientation towards the atypical, those aspects of human life and character that do not conform to the normative. If there is a single overarching theme that lends the work a modicum of cohesiveness, it is the omnipresence of time in its various modes and rhythms. These range from the slowly passing, barely perceptible time of sensations, often re-experienced with pleasure and longing, to that severely focused and urgent time that intensifies our remaining moments and consciousness of imminent end. Time is the touchstone of all other investigations and the supreme catalyst for change, confusion, disorder and dysfunction, as Nula reflects. ${ }^{8}$ The text embraces not only time but the consequences of time, not in the usual spirit of regret but rather with special emphasis on the other sides of loss, silence,

\footnotetext{
${ }^{8}$ La grande, p. 300.
} 
distance and dysfunction. It is a text too that reverses Cartesian hierarchies: sensation takes precedence over the intellect and freshness of perception, even that deriving from wineinduced inebriation, is preferred to conventional attitudes and perspectives. The title, $L a$ grande, gestures beyond the empirical experience of the here and now - governed by an appearance of coherence and continuity - towards a larger, enclosing temporal framework that cannot be identified clearly, although some characters, notably Gutiérrez, have a clear intuition of its existence, as we shall see. ${ }^{9}$ La grande may be less convoluted and opaque than some of Saer's other texts - the short story, 'La mayor', being the most graphic example ${ }^{10}$ - but, in common with them, it undermines reason alongside its foundations in ostensible coherence and continuity. In their place, it foregrounds the value of feelings and sensations which do not depend, of course, on the intellect.

The absence of a final chapter, along with the missing conclusion, reinforces our sense of textual lack, incoherence and discontinuity. In La grande, attributes such as reason, normally seen as positive, are 'disabled': in an early episode, two of the main characters, Gutiérrez and Nula, are presented with a couple of fish which Chacho, an associate of Escalante, Gutiérrez’s friend, takes directly from the water and guts before handing them over. In the darkness, a circle of light illuminates fragments of various items at random: 'momentos inconexos del espacio y del tiempo flotando en la negrura que a Nula le parecen constituir

\footnotetext{
${ }^{9}$ Linenberg-Fressard refers to the symphonic aspects of the text based on its reference to Beethoven’s Great Fugue ('La ciudad en el tiempo’, p. 360).

${ }^{10}$ Cuentos completos 1957-2000, Biblioteca breve (Buenos Aires: Seix Barral, 2001), pp. $125-44$.
} 
una versión más correcta del mundo empírico que, en la somnolencia diurnal en la que los mantiene la tiranía de lo razonable, los hombres se han habituado a considerar con la doble superstición de la coherencia y de la continuidad’ (pp. 58-59). Here images of the circle, chance, disorder, fragmentation and 'negrura' - assert their dominance over the twin 'superstitions' of coherence and continuity. This 'negrura' is often located in the human mind which, we read, is like a pond - the lower part being dark with 'sedimientos arcaicos', full of ‘sombras confusas y sin forma reconocible’ (151). These associations may sound negative but for Saer they are not necessarily so: it is the light (rather than this 'negrura') along with its associated clarity and transparency that is sinister, largely because it is deceptive and misleading. In Nadie, nada, nunca, February is the 'mes irreal' because of its 'luz cruda, implacable’. The light envelops things, ‘sometiéndolas a una inmovilidad ardiente, de diamante, en lo que todo está inerte y nítido, seco y cruel’. ${ }^{11}$ In this respect, light stands at the opposite pole to time which is, of course, associated with change rather than with stasis. ${ }_{-}^{12}$ Nula is the protagonist. His name is the Arabic equivalent of Nicholas. ${ }^{13}$ We read that Yusef, his grandfather, had arrived from Damascus in the 1920s. ${ }^{14}$ His situation is similar, therefore,

${ }^{11}$ Saer, Nadie nada nunca, Rayos globulares, 13 (Barcelona: Rayo Verde. 2014 [1980]), p. 77, $183-84$.

${ }^{12}$ Saer's views of rationality are reminiscent of those of the Spanish writer, Manuel Vázquez Montalbán (1939-2003) as expounded in his 'Manifiesto subnormal’: ‘El prestigio de la razón ha sido una de las institucionalizaciones culturales mejor establecidas por la burguesía’. Escritos subnormales (Barcelona: Grijalba Mondadori, 1995 [1989]), p. 42.

${ }^{13}$ La grande, p. 78.

${ }^{14}$ Ibid., p. 81. 
to Saer's, who was a second generation Arab. ${ }^{15}$ Nula's Arab identity emerges occasionally, for example, Gabriela, an acquaintance, deduces from Nula's strong facial hair growth that he is of Arabic origin (p. 167); and Nula explains the Arabic origin of his name to both his lovers, Lucía (p. 133) and Virginia (p. 147). La grande, therefore, calls into question Civantos's claim that Saer 'makes little to no reference to things Arabic'. ${ }^{16}$ Though well integrated in society, Nula as Arab may be seen as a figure of the other. This, is in keeping with the text's underlying concern with a series of dichotomies: - the other of reason (incoherence and discontinuity); the other of the normal (physical and psychological disabilities); the other of everyday, chronological time; the other of visible reality; and the other of 'normal' novelistic practice.

\section{Disability and the Other}

The other is a concept closely associated with disability: Davis points out that society 'singles out disability as the other and defines itself by that other'. ${ }^{17} \mathrm{He}$ also emphasizes the

\footnotetext{
${ }^{15}$ Christina Civantos, Between Argentines and Arabs. Argentine Orientalism, Arab Immigrants, and the Writing of Identity (Albany: State University of New York Press, 2006), p. 18.
}

${ }^{16}$ Ibid,, p. 226, note 26

${ }^{17}$ Lennard J. Davis, 'Bodies of Difference: Politics, Disability, and Representation', in Disability Studies: Enabling the Humanities, ed. by Sharon L. Snyder, Brenda Jo Brueggemann, and Rosmarie Garland-Thomson (New York: The Modern Language Association of America, 2002), pp. 100-108 (p. 106). 
supremely transgressive and deviant figure represented by the disabled body. ${ }^{18}$ GarlandThomson makes a similar point, noting that disability 'confounds any notion of a generalizable, stable physical subject' ${ }^{19}$ Saer's fiction is replete with literal and metaphorical manifestations of disability, ranging from the case of el Ladeado of El limonero real whose ‘cuerpo torcido’ blights his existence, his father seeing it as a source of bad luck ${ }_{2}{ }^{20}$ to that of Waldo of La ocasión, ${ }^{21}$ who is affected both physically and mentally, to the 'mad' characters of Las nubes whose disabilities are mainly psychological, such as the younger of the Verde brothers, 'Verdecito', who displays symptoms of Tourette’s disease, routinely repeating phrases addressed to him. ${ }^{22}$ On some occasions, characters suffer a temporary form of psychological disablement, such as Elisa of Nadie nada nunca, who is deprived of individual will and agency by dark forces that control her movements. ${ }^{23}$ There are also instances of emotional disablement such as that of Gina, also of La ocasión, whose acceptance of

${ }^{18}$ Leonard J. Davis and American Council of Learned Societies, Enforcing Normalcy: Disability, Deafness, and the Body (London; New York: Verso, 1995), p. 5.

${ }^{19}$ Rosemarie Garland-Thomson, Extraordinary Bodies: Figuring Physical Disability in American Culture and Literature (New York: Columbia University Press, 1997), p. 24.

${ }^{20}$ Saer, El limonero real, Biblioteca breve, $9^{\text {th }}$ edn (Buenos Aires: Seix Barral, 2015 [1974]), p. 39.

${ }^{21}$ Saer, La ocasión, Colección Ancora y delfín, 614 (Barcelona: Ediciones Destino, 1988).

${ }^{22}$ Saer, Las nubes, Biblioteca breve, $7^{\text {th }}$ edn (Buenos Aires: Seix Barral, 2008 [1997]), p. 134.

${ }^{23}$ Saer, Nadie nada nunca, p. 165. 
Bianco’s marriage proposal, while maintaining her usual detached and impassive demeanour, strikes a jarring note. ${ }^{24}$

In La grande, one of the leading characters has a notable physical disability: Nula is married to Diana, the attraction grounded not only by her extraordinary beauty but partly also by her disfigurement. Following complications at birth, she lacks a left hand, her arm ending in a stump: ‘Al nacer, Diana había aparecido en el mundo con el cordón umbilical enredado en la muñeca, de modo que tuvieron que operarla y le faltaba la mano izquierda’. ${ }^{25}$

Loss complements the other as a key focus in this text: physical loss is accompanied by other forms of loss such as loss of youth (Leonor), loss of time in the zona (Gutiérrez, who spends thirty years in France), the loss of summer as autumn arrives, the loss of an ending as the narrative falters with the loss of its author. ${ }^{26}$ Overshadowing all is the loss of faith in reason as incoherence and discontinuity become dominant. These losses all stem from the inevitable movement of time, sustaining the narrative that attains its full meaning 'when it becomes a

\footnotetext{
${ }^{24}$ La ocasión, p. 136.

${ }^{25}$ La grande, p. 104.

${ }^{26}$ Discussing Benjamin’s The Origin of German Tragic Drama, Judith Butler refers to the problem of loss that emerges when established narratives begin to falter, suggesting that narrative functioned once as a way of containing loss. 'Afterword: After loss, What then?', in David L. Eng and David Kazanjian (eds), Loss: the Politics of Mourning (Berkeley, Los Angeles and London: University of California Press, 2003), pp. 467-73 (p. 469). The sense of an abrupt ending conveyed at the conclusion of La grande ranks, in my book, as one of the most poignant expressions of literary loss.
} 
condition of temporal existence'. ${ }^{27}$ Short time spans (the change of seasons) are interspersed with relatively long ones (Leonor's ageing process), to suggest a time that is textured and multifaceted, that is both rapid and attritional. The text allows time to do its work - whether as wilful destroyer in the case of Leonor or as conscious artist whose techniques are appreciated by Gutiérrez through his intuitions of a larger mythic time. He is seemingly rewarded for his devotion, being spared the fate of the time-ravaged Leonor. ${ }^{28}$

\section{Nula: Residues of Reason}

While Nula is conscious of the artificiality of reason, he is himself subject to its tyranny, as is clear in his determination to find an explanation for Lucía’s behaviour in stopping at symmetrical points on the block 'para el cual tanto la finalidad como el comportamiento tenían que ser racionales'. ${ }^{29}$ Such insistence is also ironic in view of Nula’s close professional connection with wine which can, of course, induce inebriation and accompanying loss of reason. Nula's urge to know is often deflated: the government adviser or consejero is given to talking about 'cosas vagas, fragmentarias, inconexas'. ${ }^{30}$ The latter's gaze, alternating between 'la fijeza y la deriva', ${ }^{31}$ eludes Nula's understanding. Here, then, is

\footnotetext{
${ }^{27}$ Paul Ricoeur, Time and Narrative, trans. by Kathleen Blamey and David Pellauer, 3 vols (Chicago and London: University of Chicago Press, 1988), i, p. 52.

${ }^{28}$ La grande, pp, 15, 392-93.

${ }^{29}$ Ibid., p. 102

${ }^{30}$ Ibid., p. 154.

${ }^{31}$ Ibid., p. 155. This image can be seen as a metafictional reference to La grande itself in view of the text's digressive aspects.
} 
a further instance of intellectual pretensions being eclipsed by the pervasive presence of incoherence and discontinuity.

Like Saer who 'llevaba un cuaderno de notas mientras escribía sus novelas’ (A.D., ‘Algunas precisiones sobre esta edición'), ${ }^{32}$ Nula carries a notebook ${ }^{33}$ where he records ideas as they occur to him. Neither his life nor, we might surmise, his writing follows the path of a straight line. His career trajectory is significant in this respect: having first considered medicine, he subsequently gravitated towards philosophy before eventually finding work as a wine salesman. He is described as being 'proclive al vagabundeo interno y exterior' and as feeling 'dentro y fuera del mundo a la vez', ${ }^{34}$ perhaps alternating too between everyday chronological time and the sense of a larger, all-encompassing time to which his friend, Gutiérrez, is in thrall._Here he emerges as a human analogue of digression: he has 'digressed' from his calling as a philosopher to become a wine salesman, returning intermittently to his 'true' métier as he populates his notebooks with thoughts that lie beyond the scope of his current work. His love affairs may be seen as ‘digressions’ from his public (and private) role as loving and solicitous husband to Diana - as well as from his professional duties. He is subject to 'fantasías recurrentes y obsesivas y pulsiones repentinas y perentorias’ 35 exemplified in his anticipation of a sexual encounter with Victoria, a professional colleague in the wine business, which makes him lose the thread of their conversation and to respond to her with hesitant monosyllables. ${ }^{36}$ Here again Nula is subject to the ineluctable forces of

\footnotetext{
${ }^{32}$ Ibid., pp. 437-38.

${ }^{33}$ Ibid., p. 181.

${ }^{34}$ Ibid., pp. 79, 161.

${ }^{35}$ Ibid., p. 259.

${ }^{36}$ Ibid., p. 310.
} 
incoherence and confusion which overwhelm the values of reason and logic to which he continues to cling.

\section{Gutiérrez’s ‘disablement’}

Nula and Gutiérrez are friends despite their age difference, the former being twenty nine and the latter twice his age. Gutiérrez may be in good physical shape but he is 'disabled' by the missing thirty years spent away from the region which has undergone significant changes during that time: his identity as a native is compromised by such an extended absence. His friends suspect, however, that he is engaged in a Proustian enterprise - to regain the time lost by returning to the past of his youth. Gutiérrez's obsession is consistent with that personal aura of self-absorption and communicative incoherence that distances him from others: his instincts go counter to that 'chrononormativity' whose objectives, according to St Pierre, are to 'eliminate friction and instantiate in our bodies and relations, the distinctly modern flow of time that is at once linear, forward-looking and uninterrupted'. ${ }^{37}$

Disability is often associated with asymmetry, representing literal and metaphorical deviation from the normative. It marks the relationship between Gutiérrez and Nula who maintain a kind of friendship despite their considerable age difference - an unusual but by no means unique situation. Escalante and his wife are also separated by a considerable age gap which accounts for Gutiérrez's initial assumption that she is his daughter. ${ }^{38}$ The character who represents the asymmetrical most graphically is, of course, Diana, whose truncated limb attracts Nula (p. 105) but disconcerts other people such as Gabriela, ${ }^{39}$ so emphasizing the

37 Joshua St. Pierre, 'Becoming Dysfluent: Fluency as Biopolitics and Hegemony’, Journal of Literary \& Cultural Disability Studies 11.3 (2017), 339-56 (p. 350).

\footnotetext{
${ }^{38}$ Ibid., p. 45.

${ }^{39}$ Ibid., p. 213.
} 
status of the disabled figure as other or stranger. The disappeared couple, Gato and Elisa, belong to a similar category, being 'atípicos', different from other people. ${ }^{40}$

According to Tomatis (one of those ubiquitous characters who feature throughout Saer's oeuvre), all the guests at Gutiérrez's asado, the text’s closing episode, are asymmetrical, standing apart from the ordinary run of people, removed from the crowd. In Saer's work, deviation from the norm and lack of conformity to conventional standards are signs of vitality and difference rather than of disadvantage and dysfunction. The conjunction of disfigurement and beauty enhances Diana's attractiveness rather than diminishes it, as we have seen.

\section{A Distant Friendship}

According to Sarlo, 'La grande es una novela de la amistad'. ${ }^{41}$ In fact, the importance of friendship is less pervasive than that of time which appears in many guises, as noted, not least as a potential source of distance between characters separated by a significant age gap, as we have seen: although Nula and Gutiérrez are undoubtedly friends, their relationship is tempered, perhaps, in some ways, even enhanced_by their lack of communication, a familiar theme of Saer's earlier texts such as La ocasión and Las nubes. The limitations of language are highlighted in Nula’s initial, one-sided exchange with Gutiérrez who 'monologa con desdén desapasionado'. ${ }^{42}$ Nula ‘únicamente pesca palabras sueltas o fragmentos de frases’. ${ }^{43}$ The 'disablement' of language distinguishes this friendship, removing it from the 'norm'

${ }^{40}$ Ibid.,, p. 230.

${ }^{41}$ Beatriz Sarlo, 'El tiempo inagotable', in Escritos sobre literatura argentina, ed. by Sylvia Saítta (Buenos Aires: Siglo XXI Editores, 2007), pp. 317-20 (p. 318).

${ }^{42}$ La grande, p. 12.

${ }^{43}$ Ibid., p. 12. 
based on mutual understanding and intimacy. Nula finds the older man 'cada vez más incomprensible y extraño’, ${ }^{44}$ a view echoed both by Moro, the estate agent, who feels that Gutiérrez occupies a different plane of reality -‘parecía que caminábamos por la misma calle, en el mismo espacio, pero en tiempos diferentes’- and by Tomatis who senses Gutiérrez’s 'misterio impenetrable'. ${ }^{45}$ Subsequently, Soldi notes that Gutiérrez gave the impression of wanting to communicate 'pero sin palabras'. ${ }^{46}$ The implication in each case is that Gutiérrez’s deviation from the norm of fluent communication and easy, if superficial, sociability, is a quality that enhances rather than diminishes his status. Communication is inevitably ‘disabled’ when language, its primary channel, is removed. Gutiérrez’s communicative deficiencies provide the most striking repudiation of fluency which, as St. Pierre notes, 'helps preserve the unity or integrity of the rational, able-bodied subject across the potentially unstable event of communication' ${ }^{47}$ This is a general problem: Nula notices the atypical mode of communicating displayed by Escalante, Gutiérrez’s friend, who seemed to address himself rather than others. ${ }^{48}$ In reality, the relationship between Nula and Gutiérrez is no more intimate than that between Nula and his boss, Américo, who is sufficiently familiar with Nula to express his suspicions about Nula’s relationship with Virginia, ${ }^{49}$ superintendent of the wine section at the Warden hypermarket. By contrast, Gutiérrez, who sees Nula with Virginia at a restaurant, does not question Nula's explanation

${ }^{44}$ Ibid., p. 396.

${ }^{45}$ Ibid., pp. 25, 408.

${ }^{46}$ Ibid., p. 418

47 Joshua St. Pierre, 'Becoming Dysfluent: Fluency as Biopolitics and Hegemony’, Journal of Literary \& Cultural Disability Studies 11.3 (2017), 339-56 (p. 349).

${ }^{48}$ La grande, p. 45.

${ }^{49}$ Ibid., p. 298. 
that he and his companion are having a 'clásica cena de negocios'. ${ }^{50}$ Gutiérrez shows some indulgence towards the youthful insolence he perceives in Nula ${ }^{51}$ but, beyond their relatively superficial camaraderie, it is distance and silence that characterize their relationship. ${ }^{52}$ Nonetheless, these aspects are not portrayed negatively since the silence, for example, heightens their sensibilities: 'Gutiérrez y Nula, sin hacer ningún comentario [...] adivinan, por los sonidos fragmentarios que les llegan de tanto en tanto, las voces o la música que conservan sus rasgos distintivos a pesar de su calidad inconexa y de su lejanía'. ${ }^{53}$ These characters are attracted to each other not by their openness but by their opacity ${ }^{54}$ and are intimidated by what its dissipation might reveal. Their silence gives each of them an enhanced experience of time, an insight into those dimensions that usually go undetected. ${ }^{55}$ When the self-absorbed Gutiérrez emerges from his reverie, he offers a light-hearted explanation: 'Estaba viajando en el tiempo - dice’. ${ }^{56}$

\section{Time}

Time dominates La grande, insinuating itself by means of the notable age differences between friends and married couples, as we have seen. The title suggests a 'pequeña summa’, ${ }^{57}$ treating several themes that are familiar to the Saer reader. Time and change are

\footnotetext{
${ }^{50}$ Ibid., p. 312.

${ }^{51}$ Ibid., p. 30.

${ }^{52}$ Ibid., pp. 27-28.

${ }^{53}$ Ibid., p.36.

${ }^{54}$ Ibid., p. 42.

${ }^{55}$ Ibid., p. 28.

${ }^{56}$ Ibid., p. 28.

${ }^{57}$ Raquel Linenberg-Fressard, 'La ciudad en el tiempo’, pp. 357-67.
} 
embedded in the structure of the text whose chapters are named after the days of the week, beginning with Tuesday and ending with Monday - a chapter that is blank, apart from one line, because the author's death supervened before its completion. Sarlo notes that Saer refers to the reader's experience of the dual aspects of time as 'densidad viscosa' and 'contradictorio fluir', ${ }^{58}$ both highlighting time’s incoherence and discontinuity. Nula is particularly sensitive to time as an unmeasurable and uncontrollable phenomenon, only superficially domesticated by human contrivances such as clocks: 'todo está en movimiento y en cambio constante'. ${ }^{59}$ He goes on to reflect that, despite constant movement, 'es imposible conocer la velocidad intrínseca a la que el acontecer sucede’, a theme to which he returns later: ‘¿Cuánto duran fuera de los relojes, los acontecimientos?’. ${ }^{60}$ He subsequently ponders 'la distancia sin medida que separa el instante actual de sus predecesores abolidos'. ${ }^{61} \mathrm{He}$ thinks of the beginning of time when ‘el gran delirio inició su expansión’ and anticipates the ultimate consequences of time on himself and Diana: old age, dementia and death. ${ }^{62}$ The passage of time erases all residual traces of reason and coherence. The human mind is divided between the transparent and the dark 'other' with no real demarcating line between

\footnotetext{
${ }^{58}$ Sarlo, ‘El tiempo inagotable’, p. 317.

${ }^{59}$ La grande, p. 81.

${ }^{60}$ Ibid., pp. 82, 114. Saer’s preoccupation with time cannot but recall Proust. Bowie remarks that 'the discrepancy between public time, measurable by events, and mental time, measurable by the development of an individual's ideas or by his changing intensities of feeling is laid bare by Proust'. Malcolm Bowie, Proust among the Stars (London: HarperCollins, 1998), p. 46.

${ }^{61}$ Ibid., p. 255.

${ }^{62}$ Ibid., pp. 316, 300.
} 
them. ${ }^{63}$ This other can be sinister, an invasive force, a negative form of delirio, that occupies the mind - 'el ronroneo autónomo y salvaje que, cuando están solos, ocupa sus pensamientos [...]' - and is dissipated only by good conversation between Nula and Soldi, another of Saer's ubiquitous characters. ${ }^{64}$ Here we have a clearly negative manifestation of 'lo real' but at least this is authentic living that may not be easy or pleasurable but nevertheless remains superior to a social reality propped up by sham and illusion.

The effects of time are perhaps most poignantly felt in the human world. Nula notices a relatively slight change in Lucía - 'tal vez un poco más macizo que cinco o seis años atrás’and is disappointed with her sexually, attributing physical changes to the effects of time that make us other even to ourselves. ${ }^{65}$ As Nula reflects, the character whose physical decline stands out most starkly is Leonor. ${ }^{66}$ Her decision, thirty years earlier, to stay with her husband rather than join her lover, Gutiérrez, had prompted the latter’s departure for Europe. When Nula and Diana sunbathe they seem peaceful and eternal but are caught in the midst of a maelstrom of change: all matter, however seemingly durable, such as rock, metal and diamonds, is subject to time's corrosive alchemy. ${ }^{67}$ Buildings deteriorate, such as the

\footnotetext{
${ }^{63}$ Ibid., p. 151.

${ }^{64}$ Ibid., p. 166.

${ }^{65}$ Ibid., p. 116.

${ }^{66}$ Ibid., p. 313, 393.

${ }^{67}$ Ibid., p. 261. Saer frequently portrays people as vulnerable to external forces which engulf or consume them: Elisa of Nadie nada nunca is a good example, as we have seen. Literal cannibalism in El entenado is mirrored by metaphorical images of consumption elsewhere: a commonplace of Argentine literature is, of course, the image of the desert, closely allied with madness, threatening to consume the 'civilized' city. For Kilgour, however, time is the 'greatest cannibal of all who envies and so preys upon all human achievements'. Maggie
} 
apartments where India, Nula’s mother, lives. Entropy, as Chambers notes, is a major source of incoherence and disorder, associated with all time-bound existence, bringing about the 'ultimate dispersal of all things into the inertia of death' ${ }^{68}$ It is notable that the Persian poet, Omar Khayyam (1048-1131), whose references to wine in the Rubaiyat are invoked by Nula, uses similar imagery to emphasize man’s short and fleeting existence: life crosses mountains like a cloud or the desert like a wind. He uses, to similar effect, metaphors of day and night and the passage of the seasons ${ }^{69}$ (the final chapter of La grande refers to a change of season, the loss of summer and the arrival of autumn). Ricoeur points out that, while all fictional narratives are 'tales of time', only a few are 'tales about time' inasmuch as in them it is the very experience of time that is at stake. ${ }^{70}$ The constant advance of time underlies the frequent references to clouds which are sometimes described as static ${ }^{71}$ but, more frequently, as being in motion and in the throes of dissolution, suggesting the effects of time, a phenomenon to which Nula is particularly sensitive. ${ }^{72}$ In this respect they contrast with sunlight that is associated with 'la más completa inmovilidad'. ${ }^{73}$ The clouds may be seen in

Kilgour, From Communion to Cannibalism: an Anatomy of Metaphors of Incorporation (Princeton: Princeton University Press, 2014), p. 40.

${ }^{68}$ Ross Chambers, Loiterature, Stages, 14 (Lincoln, NE: University of Nebraska Press, 1999), p. 99.

${ }^{69}$ The Great Umar Khayyam: a Global Reception of the Rubaiy, ed. by A.A. Seyed-Gohrab (Leiden: Leiden University Press, 2012), p. 16.

${ }^{70}$ Paul Ricoeur, Time and Narrative, iii, p. 101.

${ }^{71}$ La grande, p. 196.

72 Ibid., p. 255.

${ }^{73}$ Juan José Saer, Las nubes, p. 190. 
their opacity and transience as suggestive of 'lo real'; the light, by contrast, exudes a superficial sense of clarity and certainty reminiscent of a false social reality.

Time is the great disabler that cannot be measured and cannot be negated: Nula senses that this is precisely what Gutiérrez is trying to do, living as though he had never been away, pretending that the world he knew before his departure had not changed. ${ }^{74}$ Soldi has similar thoughts, reflecting that Gutiérrez had embalmed his youth in his memory. ${ }^{75}$

The experience of time was, of course, a more personal and poignant issue for Saer who wrote this text with the knowledge that he was dying: Monteleone describes La grande as ‘una agonía literaria [...] una lucha, una pelea, menos contra la muerte que contra el tiempo [...]'. ${ }^{76}$ In ordinary circumstances, time may appear benign, a taken-for-granted aspect of life that barely impacts either on the body (at least visibly) or on day-to-day consciousness. In exceptional situations, however, notably the proximity of death, the reverse side of time comes to the fore: its barely perceptible progress in ordinary circumstances is transformed into a fearful foreshortening as it assumes an all-consuming presence heightened by knowledge of its immanent exhaustion.

${ }^{74}$ La grande, p. 50, 311.

${ }^{75}$ Ibid., p. 399.

76 Jorge Monteleone, ‘Lo póstumo: Juan José Saer y La Grande’, Ínsula, 711 (2006), 14-17

(p. 15). Premat's observation that the first draft dates back to 1995 indicates that Saer had spent ten years on a text that remained unfinished when he died in 2005. Julio Premat, ‘Introducción general’ in Juan José Saer, Papeles de trabajo (Buenos Aires: Seix Barral, 2012), pp. 7-24 (p. 14). 
The reverse side of things, the inaccessible aspect of 'lo real', is much in evidence: Tomatis looks at a photograph of a literary association, 'El Grupo Precisionista', in an old copy of the newspaper, La Región: it is like 'la superficie engañosa de un espejo en cuyo reverso hierve un tumulto de contradicciones'. ${ }^{77}$ Gutiérrez’s warmth and generosity are genuine according to Tomatis 'pero algo oscuro parece que se tramitara detrás de ellas, no contra los otros sino contra sí mismo'. ${ }^{78}$ The dark other of people has its counterpart in 'el reverso negro del acontecer' ${ }^{79}$ which is bound up with the inscrutable forces of destiny. Social reality is based on the visible, appearances and make-believe: as Mitchel and Snyder state: “"reality” is merely an effect of the duplicity of language, a false leg that cannot quite replace the lost original'. ${ }^{80}$ Gutiérrez appears to dispense with this false leg at the cost of having to confront his inner darkness, achieving a kind of authentic consciousness but burdened by constant proximity to 'lo real'. This character's experience is magnified by Saer whose text, his most personal, is conditioned by his own biographical circumstances. Its digressive style suggests a writer attempting - irrationally - to escape death by prolonging the preliminaries indefinitely, aiming to 'maintain against the definitiveness and completeness of the end, the potentialities of the beginning'. ${ }^{81}$

\footnotetext{
${ }^{77}$ La grande, p. 363.

${ }^{78}$ Ibid., p. 370.

${ }^{79}$ Ibid., p. 91.

${ }^{80}$ David T. Mitchell and Sharon L. Snyder, Narrative Prosthesis: Disability and the

Dependencies of Discourse (Ann Arbor: University of Michigan Press, 2000), p. 12.

${ }^{81}$ Olivia Santovetti, ‘Straight Line or Aimless Wandering? Italo Calvino’s Way to

Digression', in Alexis Grohmann and Caragh Wells, eds., Digressions in European
} 


\section{Sensations}

Time is a key theme, therefore, and is linked to another, wine, which is unique in its improvement rather than deterioration with age. As in previous texts, particularly Nadie nada nunca, sensations, that do not depend on language or on the intellect, are often prioritized over thoughts as Saer reinforces his focus on the body in preference to the mind ${ }^{82}$ Here he is

Literature: from Cervantes to Sebald (Basingstoke and New York: Palgrave Macmillan, 2011), pp. 169-80 (p. 170).

${ }^{82}$ David Hillman and Ulrika Maude note that the body has always been a contested site. In the Christian and Humanist traditions, it has often been seen as a mere auxiliary to the self, a vehicle or object that houses the mind or the soul, 'Introduction', in David Hillman and Ulrika Maude (eds), Cambridge Companion to the Body in Literature (Cambridge: Cambridge University Press, 2015), pp.1-9, (p. 1). Virginia Woolf makes a similar point: 'literature does its best to maintain that its concern is with the mind; that the body is a sheet of plain glass through which the soul looks straight and clear, and, save for one or two passions such as desire and greed, is null and negligible and non-existent'. 'On Being Ill', in The Moment and Other Essays (London: Hogarth, 1947), pp. 14-24 (p. 14). Saer conceives of writing in terms of bodily movement and sensation rather than of intellect: 'Mecerme en el equilibrio infrecuente y perecedero de la mano que va deslizándose de izquierda a derecha, oyendo los rasguidos de la pluma sobre la hoja del cuaderno, victorioso por el hecho de haber comprendido por fin que el deseo de escribir es un estado independiente de toda razón y de todo saber, liberado de toda exigencia de estructura, de estilo o de calidad, y lleno del silencioso clamor de las palabras que no son de nadie [...]’. Julio Premat, 'Introducción 
strongly reminiscent of Proust for whom sensation was to be valued above intellect since memories conjured up by contingent sensory stimuli can put us in touch with 'the intimate essence of ourselves' in a way that the intellect cannot. ${ }^{83}$ The young Nula and his brother, Chade, experience their first sensations of the llanura and its horses:

sensaciones táctiles por ejemplo: el contacto caliente y palpitante contra el cuerpo del caballo sudoroso [...] O si no olfativas: el olor de los paraísos, de las madreselvas y de los ligustros en flor [...] O gustativas: el sabor de la bebida hecha con uvas verdes [...]. Auditivas: el espacio negro de la noche que se descomponía en una multiplicidad de planos diferentes cuando, por una razón cualquiera, los perros del pueblo empezaban a ladrar y a responderse en la oscuridad [...]. Y también visuales: el horizonte vacío de la llanura, irreal y [...] siempre idéntico a sí mismo. ${ }^{84}$

His sensations, allied to memory, take Nula back to a distant past which points to the relative joyousness of La grande in contrast with previous works, notably 'La mayor'. Here Proust's madeleine and the memories aroused by its taste are evoked but for negative purpose, not to portray an enriching return of the past but rather to reinforce the sterility of the present: 'Sopo la galletita en la taza de té [...] y alzo, rápido, la mano hacia la boca, dejo la pasta azucarada, tibia, en la punta de la lengua, por un momento y empiezo a masticar, despacio, y ahora que trago, y ahora que no queda ni rastro de sabor, sé, decididamente, que no saco nada, pero

general’, in Juan José Saer, Papeles de trabajo (Buenos Aires: Seix Barral, 2012), pp. 7-24 (p. 7).

${ }^{83}$ Adam Watt, The Cambridge Introduction to Marcel Proust (Cambridge, Cambridge University Press, 2011), p. 40.

${ }^{84}$ La grande, pp. 83-85. 
nada, lo que se dice nada’. ${ }^{85}$ By contrast, Nula, experiences a rich variety of memories associated with the different senses. Saer's digressive mode enhances the bodily bias of the text, removing it further from the rigid structures associated with the intellect. Grohmann and Wells note that

a bodily aesthetic emanates from the art of digressive writing, one that seems to be more in tune with the intangible rhythms of the human body and also the unconscious patterns of desire that are held in check by conventional morality [...]. Digression, accordingly, serves as a trope for an exploration of a more primal, libidinal energy that challenges the ordered structure of traditional thought and modes of behaviour. ${ }^{86}$

Physical sensations fill Gabriela with satisfaction. ${ }^{87}$ She recalls the sensations she experienced during lovemaking with José Carlos: ‘en ese momento las sensaciones recorrían todo su cuerpo y lo llenaban hasta el último pliegue, sin dejarle ningún lugar al pensamiento [...]'. ${ }^{88}$ Similarly, Gutiérrez’s amorous sensations, experienced for the first time during lovemaking with Leonor, return from the distant past to overwhelm him. He still delights in

${ }_{85}^{85}$ 'La mayor’, Cuentos completos, pp. 125-44, p. 125

${ }^{86}$ Alexis Grohmann and Caragh Wells. 2011. 'Introduction', in Digressions in European Literature. From Cervantes to Sebald, ed. by Alexis Grohmann and Caragh Wells (Basingstoke: Palgrave Macmillan, 2011), pp. 1-8 (p. 5).

${ }^{87}$ La grande, p. 203.

${ }^{88}$ Ibid., p. 205. 
simple sensations such as that of the dew on the grass that dampens his feet through his sandals. ${ }^{89}$ All his guests enjoy the reassuring 'olor del asado' ${ }^{90}$ at the close. ${ }^{91}$

Wine serves as a catalyst for sensuous living. It releases 'el otro, o lo otro - la otredad que buscamos [...]. Sobrios estamos como expulsados de nuestra vida interior; la ebriedad nos la restituye'. ${ }^{92}$ Madness can be a form of intoxication (pp. 284-85). ${ }^{93}$ The taste of wine cannot

${ }^{89}$ Ibid., p. 380.

${ }^{90}$ Ibid., p. 385.

${ }^{91}$ With their minds largely deactivated, the characters of Nadie nada nunca experience the world almost exclusively via their sensations. The narrative focuses on the activities of the body and of the senses to the virtual exclusion of the mind: eating (p. 41); the sense of smell which seemingly provides the only source of stimulation for El Gato (pp. 47; 211); drinking (p. 74); taste (p. 197). When El Gato strokes a horse, it is his sensations rather than his thoughts that are described (p. 215). More strikingly, when he reads Sade, the focus is not on his intellectual response but on his awakening sensations and heightened awareness of his surroundings, although the objects that make up his physical world suddenly 'se transforman a su vez en abismo, en presencia sin fondo [...]' (p. 172).

${ }^{92}$ La grande, p. 284.

${ }^{93}$ Ortega y Gasset identifies Dionysus as ‘el dios borracho’ and ‘dios-vino’ and ‘lo dionisíaco’ as ‘algo más allá de la personalidad’. ‘La personalidad es conciencia, deliberación, cautelosa y suspicaz previsión, regimentada conducta, razón [...]. La entrega a Dionysus y la realidad trascendente que él simboliza es la enajenación, la locura estática $-<$ la manía>’, José Ortega y Gasset, Idea del teatro (Madrid, Revista de Occidente, 1958), pp. 7578. 
be expressed by language, only alluded to by metaphors and comparisons. ${ }^{94}$ Wine gives rise to a mass of sensations that exceed any linguistic signifier. In this respect, wine can be linked to sex which also produces sensations that elude language: when her husband, Dr Riera, makes love to Lucía, 'lo innombrable, lo inconcebible se estaba produciendo'. 95

Wine challenges the supremacy of conventionalized behaviour ${ }^{96}$ governed by the delirio of everyday life. It promotes a swerve from the banal chronological rituals of life and infuses the observer with a welcome freshness of perception. Significantly, it is the wine salesman, Nula, who is the source of such defamiliarizing perspectives: 'Lo extraño del mundo no son sus confines impensables y distorsionados, sino lo inmediato, lo familiar. Basta una mirada ajena, que a veces puede provenir de nosotros mismos, por fugaz que sea, para revelárnoslo’. ${ }^{97}$ There is subsequent reference to the benefits of a temporary non-toxic drunkenness that facilitates new perspectives. The individual sees himself and the world differently, the banal is enriched and the familiar made strange - all due to that 'otherness' deriving from wine: ‘una ebriedad pasajera, no tóxica, que asalta al sujeto de un modo súbito, haciéndolo cambiar de estado y verse durante unos instantes y ver a la vez, al mundo diferente, extraño, en un estado transitorio durante el cual lo banal se enaltece, lo familiar se vuelve remoto y, lo desconocido, familiar. Esta ebriedad inmotivada, que puede causar exaltación o pánico,

\footnotetext{
${ }^{94}$ La grande, p. 256.

${ }^{95}$ Ibid., p. 277.

${ }^{96}$ Saer is particularly sensitive to conventionalized behaviour referring, for example, to the present time as one in which 'el estereotipo y el comercio pretenden transformer en letra muerta toda palabra, pronunciada o escrita’. 'Hugo Gola', in Trabajos (Buenos Aires: Seix
} Barral, 2006), pp. 159-66 (p. 166).

${ }^{97}$ La grande, p. 138. 
pone en contacto con la otredad tan buscada a través del vino'.98 The literary connotations of wine are emphasized through reference to the ‘aura literaria que caracteriza al producto’. ${ }^{99}$ The usually banal, utilitarian function of the labels of the wine bottles in the hypermarket - to convey a message - is subordinated to their artistic associations: 'pierden su función representativa o comunicativa y se vuelven guarda o arabesco'. 100 The artistic aspect of wine is further represented by reference to Omar Kayyam's Rubaiyat where the praise of wine is always accompanied by the denunciation of such traditional values as power, religion, and conformity - which, of course, underlie social coherence. Nula, however, cannot make similar criticisms since they would offend the rational or religious sensitivities of the consumer. ${ }^{101}$

\section{Digression}

As we have noted, wine facilitates a swerve from banal ritual through its powers of intoxication which can interfere with the normal pursuit of daily activities based on habit and reason. It can be responsible for metaphorical digressions from the 'right' rule or path by interrupting the ordering power of human discourse and thought. La grande itself can be seen as an 'intoxicated' text, deviating at every turn from the straight line of conventional narrative. Traditional novelistic norms are disabled. It is difficult to identify a central purpose

\footnotetext{
${ }^{98}$ Ibid., p. 285. Proust comes to mind again: Hughes notes that the narrator of À la recherche du temps perdu is seemingly reborn into a new world of perception through alcohol: in his case, colour 'gains a fresh, exciting, virginal character'. Edward Hughes, Marcel Proust: $a$ Study in the Quality of Awareness (Belfast: Queen’s University, 1981), p. 90.

${ }^{99}$ La grande, p. 25.

${ }^{100}$ Ibid., p. 149.

${ }^{101}$ Ibid., p. 174.
} 
or a clear connecting thread: while Diana is a human analogue of a text with a missing component, Nula, as nomad and drifter, is a perfect figure for a text whose structure is constantly undermined by interruption and digression. Like many of its characters, La grande is atypical, failing to conform to the novel as a 'form centrally concerned with the norm'. ${ }^{102}$ It is also an emphatically self-conscious text, abounding in literary allusions, particularly to realism: Gabriela’s aunt Ángela, for example, has nothing of the resigned, dark or sad traits that many nineteenth-century novels attribute to their spinsters. ${ }^{103}$ A similar reference appears at the close when the storm breaks and the description of eight people around the table at Gutiérrez's asado recalls a scene in a realist work. ${ }^{104}$ The implication is, of course, that La grande as a whole, not just aunt Ángela, is removed from the typically unselfconscious nineteenth-century novel. Reflecting on bed-time stories, Soldi concludes that he and other readers would not have wanted long episodes with excessive details that might delay plot development or cause the denouement to be cut. ${ }^{105}$ Soldi's remarks may be read as an ironic metafictional reference to La grande, open as it is to criticism that its plot line is skewed by excessive detail and free-wheeling digression. The most incisive metafictional reference, however, is provided by Gabriela who discusses Tomatis's definition of the novel form as 'el movimiento continuo descompuesto' ${ }^{106}$ - a further image of

${ }^{102}$ Lennard J. Davis, 'Bodies of Difference: Politics, Disability, and Representation’, in Disability Studies: Enabling the Humanities, ed. by Snyder, pp. 100-108 (p. 103).

\footnotetext{
${ }^{103}$ La grande, p. 201.

${ }^{104}$ Ibid., p. 429.

${ }^{105}$ Ibid., pp. 189-90.

${ }^{106}$ Ibid., pp. 193, 200.
} 
incoherence and lack of continuity. This description can be applied to La grande whose narrative movement is continually interrupted by the seemingly arbitrary focus on banal activities. The most graphic example is the detailed description of Gabriela removing a loose button on her blouse and sewing it back on. ${ }^{107}$ The fine procedures involved, including her patient efforts to thread the needle, are described in meticulous detail, with close attention to the delicacy of the operation and to the time it requires. Here the style recalls Barthes's remarks on Bouvard et Pécuchet and Flaubert's evocation of taut clothes lines: 'Here I enjoy an excess of precision, a kind of maniacal exactitude of language, a descriptive madness' ${ }^{108}$ The four-page exposition of a largely mechanical task is not an isolated case; shunning plot development, action, suspense, denouement, this novel is truly 'disabled' in one sense but enriched in another by its focus on what is normally elided - the performance of a routine repair. Here the reader's first reaction might be to question the purpose of such detailed description which goes against 'normal' expectations of narrative coherence and continuity associated with a clear connecting thread. The episode disappoints such expectations but it does, nonetheless, offer a range of positive features. It shows, for example, the pleasure that Gabriela derives from the performance of an unremarkable activity whose potentially annoying aspects - the persistent failure to thread the needle - give rise to amusement rather

\footnotetext{
${ }^{107}$ La grande, pp. 206-11. In his discussion of Henry James, Bell notes that 'embroidery and sewing are entirely appropriate for the ways in which digressive metaphor ebbs and flows, weaving itself in and out of the main narrative'. Ian F.A. Bell, 'Henry James, in Parenthesis', in Digressions in European Literature. From Cervantes to Sebald, pp. $64-81$ (p. 66).
}

${ }^{108}$ Roland Barthes, The Pleasure of the Text, trans. Richard Miller (New York: Noonday Press, 1975), p. 26. 
than frustration at 'wasting time'. Here Gabriela refuses to adopt conventional attitudes. As for Saer, he is exploring those usually overlooked contours of human experience. ${ }^{109}$ This is a classic case of defamiliarization where a freshness of perception attends what is usually considered a routine chore, exemplifying Nula's observation that the strangeness of the world lies in the immediate and the familiar (p. 138) and justifying Gutiérrez's pleasure in the most banal of things such as 'una palabra que se le había olvidado después de tantos años y que alguien pronunciaba en la calle al pasar, o la manera de comportarse de unos chicos a la salida de la escuela [...]. ${ }^{110}$ This episode is followed by an inventory of Gabriela's bathroom accessories that sparkle following the maid, Maruca’s thorough cleaning: 'espejos, mosaicos, metales, azulejos, bañadera, pileta, inodoro, o bidet [...] descansan limpios y brillantes [...]', ${ }^{111}$ an enumeration that gives way to a less detailed but equally redundant focus on Gabriela's routine activities (urinating among them). Such close narrative perspectives recur

${ }^{109}$ This perspective might be seen as a form of minimalism, in this case, focusing on small and apparently insignificant routines. Motte remarks that what saves minimalism from banality is that it 'reinvests the ordinary with interest and attempts to persuade us that the apparent banality of our quotidian experience deserves immediate, direct examination’. Warren Motte, Small Worlds: Minimalism in Contemporary French Literature (Lincoln and London: University of Nebraska Press, 1999), p. 6.

${ }^{110}$ La grande, p. 371. Chambers notes that it is the moments of 'deviation' that prompt a freshness of perception in the reader, challenging him/her to see in ways that run counter to the 'disciplined and the orderly, the hierarchical and the stable, the methodical and the systematic showing them to be unpleasurable, that is, alienating' (Chambers, Loiterature, Stages, 14 (Lincoln, NE: University of Nebraska Press, 1999), p. 10.

${ }^{111}$ La grande, p. 211. 
subsequently when Nula's sensations while taking a shower are described followed by an inventory of the items he collects: 'Cuando está listo recoge llaves, la lapicera, cartera, tarjetas de crédito, unas monedas que estaban en la mesa de luz [...]'. ${ }^{112}$ In these cases, particularly that relating to Gabriela’s sewing, the narrative reduces time to virtual insignificance or, at least, defies its usual pressures, providing thereby a counterweight to the urgency of a time fast running out, as experienced by Saer.

La grande's digressive character takes the form too of personal musings, often excursions into the past. The world of action is balanced by that of introspection and the time of the inner self replaces the chronology of the outer world. Such excursions are recent in the case of Gabriela, who, as we have seen, reflects on her lovemaking with José Carlos following the discovery that she is pregnant, ${ }^{113}$ relatively distant in that of Nula who recalls spending the summer as a twelve year old with his uncle Enzo, ${ }^{114}$ recapturing the sensual and sexual experiences of childhood in striking detail. He recalls how 'la Rosilla se inmovilizó torciendo ligeramente la cabeza hacia atrás y elevándola un poco, tal vez para concentrarse mejor en sus sensaciones [...]'. ${ }^{115}$ Digressions often interrupt the more 'serious' aspects of the

${ }^{112}$ Ibid., p. 283. It is clear here that Saer is parodying the realist text which, as Hamon notes, is characterized by 'a marked redundancy and foreseeability of its content [...]. The most extremely typical scene, where the narrative tale coincides most closely with the linguistic task of denomination, is the scene of the inventory'. Philippe Hamon, 'Philippe Hamon on the Major Features of Realist Discourse', in Lilian Furst (ed.), Realism (London and New York: Longman, 1992), pp. 166-85 (p. 173).

${ }^{113}$ La grande, p. 205-06.

${ }^{114}$ Ibid., p. 243-50.

${ }^{115}$ Ibid., p. 249. 
narrative and fly in the face of the constraints normally imposed by time pressures. When Soldi and Gabriela talk to Nula through their open car windows, Gabriela launches into a lengthy account of her research in response to Nula's enquiry about the 'vanguardias locales'. ${ }^{116}$ Her narrative is subject to various interruptions - the sound of an approaching horse; ${ }^{117}$ Soldi’s intervention regarding Tomatis’s consultation with Brando about the disappearance of Elisa and Gato; the shift in narrative focus to Nula’s sexually-inflected scrutiny of Gabriela’s expression (p. 173); ${ }^{118}$ Nula's reflections on his recent discussion with Diana about the use of Omar Khayyam's verses in wine publicity materials; his renewed attention to Gabriela; the switch to her perspective; and her delight at the news of her pregnancy. Then, finally, she returns to the subject of her original narrative and its protagonists, Gutiérrez, Calagno and Brando. ${ }^{119}$ This pattern of narrative interruption and digression demonstrates how La grande itself conforms to Tomatis's definition of the novel as 'el movimiento continuo descompuesto' ${ }^{120}$ and thereby both undermines intellectual notions of coherence and continuity and suggests the synchronicity of time and its multiple movements.

By comparison with its predecessors, this is a relatively joyful text, illustrating 'el lado gozoso' of Saer's fictional world. ${ }^{121}$ The surface qualities of the characters - for example, in

\footnotetext{
${ }^{116}$ Ibid., p. 168.

${ }^{117}$ Ibid., p. 170.

${ }^{118}$ Ibid., p. 173.

${ }^{119}$ Ibid., pp. 174-75.

${ }^{120}$ La grande, p. 193.

${ }^{121}$ Miguel Dalmaroni, La vuelta incompleta (una pintura) (Buenos Aires: bazaramericano.com, 2005), pp. 1-5 (p. 1).
} 
the case of Nula, sociability, intellectual pretension and sexual adventurousness - serve as a counterweight to their dark reverse side, most clearly on show in the case of Gutiérrez, but also in other characters too, such as Gabriela’s mother who is afflicted by ‘algo incomprensible, que despierta la perplejidad y por momentos el odio, la invasión lenta y, al parecer sin regreso del desgano'. ${ }^{122}$ It is difficult to find any redeeming feature in such a manifestation of 'negrura'. Like its predecessors, La grande offers no reassurance or meaning. In fact, the blankness of the final chapter underpins Saer's most graphic, albeit involuntary, demonstration of some of his key terms, in particular, nada and vacío.

\section{Un lugar más grande}

Temporality is re-temporalized incessantly: some of the characters, including Gutiérrez and Leonor, have a common past 'como si, ya inmodificable, hubiese sucedido en una dimensión diferente a este en la que están ahora, hecha de espacio y de tiempo, de vacilación y de incertidumbre'. ${ }^{123}$ There is, however, yet another dimension: Gutiérrez senses the presence of a larger world beyond the immediate one that is subject to the negative influences of routine and time: 'un lugar más grande que aquel en el que, en las redes de la costumbre, se tiene la ilusión de estar'. ${ }^{124}$ Monteleone notes that 'Lo grande tiene, además, el significado

\footnotetext{
${ }^{122}$ La grande, p. 194.

${ }^{123}$ Ibid., pp. 410-11.

${ }^{124}$ Ibid., p. 380. These temporal categories parallel those identified by Reati as 'realidad superficial' and 'realidad profunda’: ‘El mundo “otro” sería entonces un mundo "hondo”, paralelo y coexistente con el de la cotidianeidad, que se asoma a veces entre las imperceptibles resquebrajaduras del mundo “normal”' (Fernando Reati, ‘”Las nubes” de Juan
} 
de un espacio que trasciende la misma condición mortal [...] Esa dimension, más grande, supone que la experiencia vital revela al mismo tiempo un carácter remoto y transitorio, su figura de espectro’. He points to Tomatis and Gutiérrez as being sensitive to this 'lugar más grande’, ${ }^{125}$ which might be seen as the reverse side of the visible. Here,

'chrononormativity' ${ }^{126}$ is replaced by a superior time, transcending both chronology and mortality. Analogously, Gabriela's thoughts focus on a matter of no importance, the choice of thread: she herself is aware that 'nadie notaría la diferencia'. ${ }^{127}$ But her self-justifying dictum that 'los distingos en las cosas menores nos acostumbran a establecerlos en las

José Saer: un viaje por la pampa hacia otra metafísica de lo real', INTI: Revista de literatura hispánica, 52/53 (2000-2001), 281-94 (p. 289).

125 Jorge Monteleone, ‘Lo póstumo: Juan José Saer y La Grande’, Ínsula, 711 (2006), 14-17 (p. 15). Ricoeur speaks of moving back 'before the fragmentation into mortal time, historical time, and cosmic time [...] in order to recall, as myth does, the idea of a 'great time' that envelops [...] all reality’. Paul Ricoeur, Time and Narrative, iii, p. 105.

${ }^{126}$ According to Freeman, chrononormativity is a 'technique by which institutional forces come to seem like somatic facts. Schedules, calendars, time zones, and even wristwatches inculcate what the sociologist Evitar Zerubavel calls “hidden rhythms”, forms of temporal experience that seem natural to those whom they privilege'. Elizabeth Freeman, Time Binds. Queer Temporalities, Queer Histories (Durham and London: Duke University Press, 2010), p. 3.

${ }^{127}$ La grande, p. 207. 
grandes’ ${ }^{128}$ leads to her reflections on philosophy just as her later anticipation of the difficulty of threading the needle brings to her mind the Biblical parable of the rich man. ${ }^{129}$ This allusiveness justifies a broader comparison and contrast with the weaving of the textual fabric: while Gabriela finally threads the needle and secures the button, Saer's digressive text offers itself as a literary counterpoint, its narrative thread too loose to bind its multifarious parts. La grande stands out in Saer's oeuvre because of the poignant circumstances under which it was written. The text was unfinished and presumably unrevised, the imaginative impulse of the writing eluding the constraints of critical revision. Delgado notes that the hallmark of Saer’s craft is ‘el trabajo lento y artesanal del lenguaje, en desconfianza permanente frente a la espontaneidad'. ${ }^{130}$ Circumstances conspired to 'disable' Saer's normal practice when he wrote La grande. In previous works, notably in Las nubes, he portrays the peculiar madness of individual characters. Here, in his final text, his portrayal of madness is less explicit though clearly discernible in episodes such as Nula's surrender to his pulsiones which dissipate his self-control. But the predominant madness of La grande is to be found in the fabric of the text itself, a text that lacks a connecting thread and clear purpose. Its insistently digressive aspects are compounded by the seemingly pointless narration of 'nonevents': the reasons for Nula’s reluctance to shelter under Gutiérrez’s umbrella ('tiene dos motivos precisos [...]'; Nula's reasons for turning on the air conditioner in his car; and the reference to Gabriela's dilemma over whether to start with green or black olives and to the

\footnotetext{
${ }^{128}$ Ibid., pp. 207-08.

${ }^{129}$ Ibid., p. 209.

${ }^{130}$ Sergio Delgado, 'Primeros días de la muerte de un escritor’, Crítica cultural 5.2 (2010) 421-32 (p. 423).
} 
maximum coach speed during Tomatis’s journey. ${ }^{131}$ Such episodes have the effect of slowing down time, of insinuating time itself as a kind of protagonist that is 'thickened' by the rehearsal of such details rather than diminished by their elision. They also indicate a procedure that is at odds with the tenets of realism: Ermarth notes that in ordinary usage we say that "someone is "realistic" who is able to sift relevant from irrelevant considerations and so to act in a manner appropriate to the situation'. ${ }^{132}$ In La grande, we have a text that, on the one hand, is missing a whole chapter while, on the other, offers an excess of information elsewhere, standing in this respect in stark counterpoint to the literary 'precisionismo' that, we read, is based on the Latin 'praecisus, "recortado, abreviado"'. ${ }^{133}$ There is, therefore, a clear lack of balance in La grande: on the one hand, there is missing text and lack of ultimate meaning; on the other, digression and the narration of pointless detail. Though madness is barely mentioned, the loose structure - devoid of such values as logical development, cohesion and purpose - suggests a narrator whose previous emphasis on madness is maintained but given a new twist. Through his style, Saer swerves away from conventional literary forms and expectations, challenging not the reader's interpretive capacities but rather her responsiveness to a text that is a testament to incoherence and discontinuity and suggestive of the disorder, impulsiveness and free-flowing imagination of madness.

It is clear that Diana’s impairment, mentioned at regular intervals, most commonly as 'muñón' ${ }^{134}$ can be seen as a physical analogue of a text that is itself incomplete, missing the

${ }^{131}$ La grande, pp. 29, 124, 224, 360.

${ }^{132}$ Elizabeth Deeds Ermarth, Realism and Consensus in the English Novel: Time, Space and Narrative (Edinburgh: Edinburgh University Press, 1998), p. 35.

${ }^{133}$ La grande, p. 325.

${ }^{134}$ Ibid., pp. 105, 258, 266, 280, 408. 
essential limb of its final chapter. ${ }^{135}$ Diana’s lack, however, is compensated by her extraordinary beauty (Nula observes that she is ‘a unos pocos dedos de la perfección' ${ }^{136}$ The text may be seen as similarly imperfect but also possessing a redeeming beauty in, for example, its depiction of the efforts at friendship made by Nula and Gutiérrez, as we have seen, and of the loyalty that Gutiérrez shows the time-ravaged Leonor (he himself has avoided physical decline, being 'sin barriga, de formas proporcionadas'. ${ }^{137}$ It also radiates warmth in its depiction of Nula as a kind of Dionysus figure with a conscience. Reminiscent of García Márquez’s Florentino Ariza of El amor en los tiempos del cólera, he is convinced that his extramarital affairs have no negative impact on his 'real' love for Diana: 'Nula la engañaba bastante, diciéndose cada vez que lo hacía que la quería de veras’. ${ }^{138}$ He refuses to lie to her: 'en su escala moral [...] el silencio resultaba todavía tolerable pero no la

${ }^{135}$ It is true, of course, that Saer did not intend for Diana to reflect the status of the text as unfinished as he clearly expected to finish the work. It is also true that, technically, Diana is not 'unfinished': she lost her hand following complications at birth rather than being born without her hand.

${ }^{136}$ La grande, p. 105.

${ }^{137}$ Ibid., p. 15.

138 Ibid., p.105. During the course of Fermina’s marriage to Juvenal, Florentino has 622 romantic liaisons. Nonetheless, he can claim in all seriousness 'Es que me he conservado virgen para ti', suggesting, of course, that these encounters had no bearing on his real love for Fermina. Gabriel García Márquez, El amor en los tiempos del cólera (Barcelona: Mondadori, 1987 [1985]), pp. 197-98, 432. 
mentira'. ${ }^{139}$ La grande is also beautiful because it avoids the repetitiveness of its predecessors as well as their unrelenting focus on the negative aspects of existence while still remaining subject to their influence. It is a text that seems to side with life - albeit life heavily inscribed by time - over nihilism, After such intense literary exercises as 'La mayor', which undermined sense and exposed the fatal shortcomings of language, it is as if Saer felt his last work should be relatively joyous and life-affirming - even as his own life was drawing to a close. Digression might be seen in this light, as a principle of untidiness, drift and disorder, undermining the 'ordering power of human discourse and thought', ${ }^{140}$ but also, positively, as life-affirming, providing moments of swerving deviation from the norm and so facilitating freshness of perception. ${ }^{141}$ Digression 'thickens' or congeals time - rather than organizes it - in a text that flaunts time’s multidimensional aspects: lost time (Gutiérrez’s absence from the region); destructive time (Leonor's body bears the physical traces of time; Nula anticipates the effects of time on Diana and himself); slow time (that of a text marked by the accretion of the redundant); phenomenological time (Gutiérrez’s consciousness of an encompassing time beyond the chronological); exhausted time (Saer's life ends before he

\footnotetext{
${ }^{139}$ Ibid., pp. 173-74.

${ }^{140}$ Ross Chambers, Loiterature, p. 113.
}

${ }^{141}$ According to Bell, ‘digression’s ties to the actual are never severed but it enables a revisiting with fresh eyes, playing with a release from formula but also with a code of sorts of its own’. Ian F.A. Bell, 'Henry James, in Parenthesis’, p. 79. 
completes his writing). Here we have a text that does not protest the inanity of the world by engaging in linguistic contortions aimed at highlighting the shortcomings of language but rather one that embraces its own lack of logic and rigour - failing to impress the stamp of order on the chaos of existence while providing a textual analogue of the unregulated flow of sensation, thereby shunning the straightjackets of reason, order and structure.

Swansea University

Lloyd Hughes Davies

Department of Modern Languages, Translation and Interpreting

Singleton Park

Swansea University

Swansea SA2 8PP

I.h.davies@swansea.ac.uk 